\title{
91 University of Glasgow
}

Ekpu, V. and Paloni, A. (2016) Business lending and bank profitability in the UK. Studies in Economics and Finance, 33(2), 302 -319.

(doi:10.1108/SEF-04-2015-0097)

This is the author's final accepted version.

There may be differences between this version and the published version. You are advised to consult the publisher's version if you wish to cite from it.

http://eprints.gla.ac.uk/111698/

Deposited on: 02 November 2015

Enlighten - Research publications by members of the University of Glasgow http://eprints.gla.ac.uk 


\title{
BUSINESS LENDING AND BANK PROFITABILITY IN THE UK
}

\begin{abstract}
Purpose - The purpose of this paper is to investigate the importance of business lending as a source of bank profits in the UK banking system. The paper also examines whether the profitability of business lending is mostly driven by heterogeneous characteristics of individual banks or whether it is affected by systematic characteristics such as bank size and ownership structure.
\end{abstract}

Design/methodologylapproach - The study uses bank level data from BankScope for a total sample of 83 UK banks and building societies. The period under consideration extends from 2005 to 2009. Econometric estimation is by panel fixed effects.

Findings: Our empirical results show that business lending is a statistically significant determinant of bank profits. However, this average effect masks important systematic differences among banks. In particular, we find strong size effects: the profitability of business lending is considerable for small banks but negligible for large banks. In contrast, we could not detect any ownership effects for domestic and foreign banks. These findings persist when the occurrence of the financial crisis is accounted for.

Research limitations/implications: Interestingly, our study relates these findings to the process of financialisation. Yet, the extent of the latter and its impact on various groups of banks (i.e., large, small, domestic and foreign banks) have not been examined. Further research in this area would make an important contribution to the literature.

Practical Implications: Our findings suggest that business lending is not a driving factor of profitability for large banks. One possible policy implication - which may be of interest especially to regulators and policy makers - is that capital injections into the larger banks per se are unlikely to lead to an expansion of credit to business.

Originality/Value: There is very little research in the literature on the questions addressed in this paper, especially for the UK banking system. Moreover, the process of financialisation, which motivates the enquiry of this paper, is a growing area of research. Thus, the contribution of this paper is twofold.

Key words: business lending, bank profitability, financialisation, UK banking system, bank size, bank ownership, panel data econometrics

Paper type: Research paper

JEL Classification: E44, G20, G21 


\section{Introduction}

The UK banking sector is one of the most important in the EU, accounting for over a quarter of all banking assets held in the EU. According to the Bank of England's Monetary and Financial Statistics, total assets of the UK banking sector amounted to over $£ 5$ trillion as at end of 2014. Relative to GDP, the UK banking sector stood at around 450 percent in 2013 (Bush et al, 2014). The UK is also the 'largest single international banking centre, accounting for about $20 \%$ of the world's cross border lending' (Kosmidou et al, 2006a). The country is one of the most open financial centres with increasing presence of foreign banks. There are 150 deposit taking foreign subsidiaries in the UK from 56 different countries. Over the past decade, foreign banks have accounted for more than 55 percent of the UK banking sector assets, with banks from EU countries accounting for 28 percent of total assets (Davies, 2002). The combined assets of the largest ten foreign subsidiaries in the UK total around $£ 2.75$ trillion (Bush et al, 2014).

The UK banking sector is characterised by the presence of a handful of very large banks, which are in a dominating position and account for a disproportionate share of the credit market, together with numerous small banks. The major lenders in the UK credit market include HSBC, Barclays, Lloyds Banking Group, Royal Bank of Scotland, Banco Santander and Nationwide Building Society. Together, these banks account for 70 percent of the stock of lending to businesses, 50 percent of the stock of consumer credit, and 75 percent of the stock of mortgage lending (Bank of England, 2014). Foreign banks control less than 15\% of the market share for loans. There are more than 80 small banks in the UK with assets ranging from less than $£ 100$ million to over $£ 10$ billion.

Despite the proliferation of banking services, business lending remains a very important component of the activities of banks and other depository institutions. In his study of European commercial banks in the 1990s, Turati (2002) reports that, almost in every country, loans to both firms and households account for about 55 percent of total bank assets with the other earning assets (e.g. bonds, shares, securities and other investments) accounting for the rest. This suggests that business lending is an important source of bank profits. Profits from lending depend on individual banks' capacity to maximise net interest earnings, reduce loan losses and minimise non-interest costs on loans.

At the same time, there is concern that this fast growth of the UK financial sector may not have been beneficial for the rest of the economy. In particular, a bigger size of the financial sector may not lead to an improvement in resource allocation. Indeed, the process of financialisation - which Epstein (2005) defines as "the increasing role of financial motives, financial markets, financial actors and financial institutions in the operation of domestic and 
international economies" - has radically transformed the relationships between financial institutions on one side and non-financial corporations and workers on the other. A feature of such transformation has been that non-financial corporations have reduced their reliance on banks by raising external finance in open financial markets while commercial banks have acquired investment banking functions and turned towards the household sector as another source of profits. As a result, the importance of traditional business lending for banks' profits has rapidly declined.

This observation prompts two interesting research questions: how important is business lending as a source of profits for UK banks? And does the answer to this question depend on individual banks' capacity and characteristics or is it possible to identify systematic characteristics of banks that affect their profitability? In this study we concentrate on two such characteristics, namely, size and ownership. We assess whether there are differences in terms of profitability between small and large banks and between foreign and domestic banks. In this study we analyse exclusively the UK banking sector. The literature on systematic bank characteristics and profitability in the UK banking system is scarce. To our knowledge, besides the influential paper by Llewellyn (2005), who found that British banks had been earning excess returns for more than a decade and that they were more profitable than their European counterparts, no major research work has examined the influence of bank characteristics on profitability. Since our study analyses contemporary profitability of banks in the UK, it also considers the effect of the global financial crisis. We feel that the impact of the latter on profitability from lending activities in UK banks is another under-researched area (other studies include Riley et al, (2014) and Bolt et al (2012). This analysis of UK banks' financial performance and of the factors that might have shaped their business models and their overall risk appetite may be of interest to bankers, regulators and policy makers.

Empirical results from our study show that corporate and commercial lending is a statistically significant determinant of bank profits, specifically the return on average equity. However, this average effect masks important differences among banks, particularly between small and large banks. For the latter, the contribution of business lending to profits is small. While the results show that bank size matters in lending performance, ownership status does not seem to matter. In other words, we found no systematic difference between domestic and UKresident foreign banks with respect to the profitability of business lending. These findings persist when the occurrence of the financial crisis is accounted for.

The rest of the paper is structured in four parts. Section 2 presents a brief overview of the expansion of the banking sector and the transformation of bank activity. Section 3 describes the empirical approach used to investigate the research questions of the paper. The choice of 
variables, sample selection and data characteristics are also discussed here. Section 4 presents and analyses the regression results. Section 5 summarises and concludes the paper.

\section{The Expansion of the Banking Sector and the Transformation of Bank Activity}

The City of London has changed beyond recognition since the 'Big Bang' in October 1986, when the UK government deregulated the London Stock Exchange to allow 100 percent outside ownership of member firms. This has led to a massive expansion of financial services. A key objective of deregulation at the time was to exploit Britain's comparative advantage in financial services, particularly given that British manufacturing was struggling to compete with low cost production in emerging economies (Dolphin, 2012).

Nonetheless, the process of financialisation started earlier, with the gradual removal of restrictions on capital flows in the 1970s and 1980s following the collapse of the Bretton Woods system of fixed exchange rates. It is an international phenomenon, even if perhaps more advanced in the UK and the US (Gart and Pierce, 1998). As a result of the dismantling of regulation, which culminated in the US with the repeal of the Glass-Steagall Act in 1999 and similar legislation elsewhere, commercial banks were able to acquire functions that are typical of investment banks - e.g., borrowing in wholesale money markets to invest in securities and earn profits through fees, commissions and proprietary trading. Such transformation of bank activity was also fuelled by waves of mergers and acquisitions which dramatically increased concentration in financial systems. Between 1991 and 1996, the UK experienced more mergers and acquisitions activity in its banking sector than any other European country (White, 1998).

Matthews et al (2007) describe competition in bank lending in the UK as monopolistic and, as mentioned above, Llewellyn (2005) finds that British banks had been earning excess returns. Similarly, the Competition Commission (2002) reports that UK banks, especially the large ones, were making unjustified excessive profits through overcharging of customers, especially small businesses, and that banking markets were characterised by weak competition.

Open financial markets made it easier for large corporations to raise external finance without relying heavily on banks. Consequently, banks restructured themselves in response to dwindling traditional business lending and, as a result, their sources of profits have changed significantly: consumer credit and financial market mediation have become increasingly important, while lending to industrial and commercial corporations much less so. Indeed, Lapavitsas (2011) notes that the enormous expansion of bank assets in the 2000s had little to do with lending to corporations for investment and was instead related to lending to individuals and to other banks. 
With reference to the US, Nersisyan and Wray (2010) report that non-interest income mostly from off-balance sheet activities but also from trading and fees - accounts for a major share of commercial banks' income and that the share of commercial and industrial loans in total assets has plummeted. Nersisyan and Wray remark that "the larger banks aren't really in the business of making loans to businesses" ( $p$ 41). Lapavitsas and Powell (2013) report a similar finding following their comparative analysis of advanced economies. Noting that the clear fall in the banks' ratio of non-FIRE (finance, insurance and real estate) corporate lending to total financial assets is, in some ways, a mirror image of the fall in corporations' share of loans to liabilities, they conclude that the large increases in finance, real estate and household lending have replaced corporate lending as the driving factor in banks' loan portfolio. According to this literature, these shifts in bank behaviour are far more accentuated in large banks than in smaller ones.

These descriptions of the financialisation of the financial system are compelling. Nevertheless, they are based on inspections of the evolution of certain financial ratios over time. In this paper we extend the empirical approach in two ways: first, we relate business lending directly to bank profitability and search for the presence of bank size and ownership effects; second, we perform an econometric analysis in which we control for a number of factors specifically, various measures of risk, bank efficiency, macroeconomic policies, business models, etc. - which are expected to have an impact on bank profitability but which have generally been omitted from the analysis.

One factor to which we devote special attention is the occurrence of the global financial crisis. The flow of new bank lending, both to UK households and businesses, fell sharply following the start of the crisis in mid-2007. Loans to the UK commercial property amounted to almost half of all the outstanding loans to UK businesses (HM Treasury, 2010). Since 2008, net bank lending to UK companies has on average continued to decline, with debt repayments exceeding new lending. This may partly reflect demand-side factors, as the demand for bank loans naturally declines during a recession as businesses scale back on inventories and capital investment plans, while tending to build up cash reserves, and it may also reflect supply-side factors, as banks tend to tighten credit supply during financial crisis, when bad debts impair their balance sheets. Moreover, as UK banks are heavily dependent on wholesale interbank funds, a shock in that market is likely to affect new credit supply. Aiyar (2011) shows that the crisis in the international funding markets resulted into a shock to UK banks' external funding and, as a result, led to a substantial contraction in domestic lending. In fact, the study found that each $1 \%$ reduction in banks' external funding caused a 0.5 percent to 0.6 percent contraction in domestic lending, which is a substantial impact. This was a significant channel for transmitting the financial shock to the real economy. Evidence from Riley et al (2014) reveals that the banking crisis is likely to have had the most adverse effect on new businesses with little existing 
collateral, businesses seeking to expand quickly and businesses with stretched balance sheets, while older and established businesses may have experienced better credit conditions. Despite the Bank of England's low interest rate policy and the decline in the cost of bank lending, the spread between the interest rate charged for new loans and the Bank Rate or LIBOR has continued to widen after the 2008 financial crisis, pointing to the relevance of supply-side explanations for the post-crisis contraction in bank lending.

\section{Data and Methodology}

\subsection{Research Hypotheses}

As discussed above, our research aims to investigate three main issues, namely, (1) the importance of business lending for bank profits; (2) whether the profitability of business lending varies systematically between small and large banks, and (3) between domestic and foreign banks. The economic literature on bank profitability motivates these research hypotheses.

While business loans are a source of income to banks and can be expected to impact positively on bank profits, excessively high loan to asset ratios may be a sign of increasing risk with possible negative repercussions on lending profitability (Bennaceur and Goaied, 2008). Indeed, Hein et al (2005) relate banks' risk profile to whether they are loan- or deposit-driven (their classification criterion is whether a bank's loan to asset ratio exceeds or falls short of 60 percent). Loan-driven banks rely mainly on purchased liabilities to fund loan growth while deposit-driven banks fund it mainly through core deposits. ${ }^{1}$

The economic literature puts forward a number of reasons why bank size may have a systematic impact on profits from lending operations. Large banks can enjoy economies of scale and make comparatively larger loans. Their client base is more likely to include stable, financially sound and well-established businesses (Haynes et al, 1999) and in general they have more diversified portfolios across regions and products (Peek and Rosengren, 1995). In contrast, small banks have been found to have informational advantages over large banks in the area of delegated monitoring and relationship lending especially to informationally opaque small businesses and consumers (see for example Petersen and Rajan, 1994; Carter et al, 2004; Berger and Black, 2011). In addition, since small banks operate mostly in rural (less competitive) markets, they tend to have higher profit potential on small business loans than large banks (Kolari et al, 1997). With regard to their respective credit risks, large banks have greater foreign credit exposures while small banks tend to have a relatively higher fraction of their portfolios as claims on other banks. .

\footnotetext{
${ }^{1}$ Core deposits consist mainly of transaction deposits plus small time deposits, which are largely insured.
} 
There may be systematic differences between domestic and foreign banks in their capacity to generate profits from their lending activities. Foreign banks are at an informational disadvantage with respect to domestic banks. Their lack of detailed knowledge of the nature and characteristics of local borrowers makes them more prone to worse lending risks. Thus, foreign banks tend to focus on multinational firms with well-known credit reputation, though this may not necessarily make them more profitable than domestic banks. In fact, there is a significant amount of evidence suggesting that foreign banks are less cost and profit efficient than domestic banks operating in the same credit market (DeYoung and Nolle, 1996; Peek et al, 1999).

Moreover, concentration in the host market tends to reduce profits for most foreign entrants and hence serves as a deterrent to entry. Nevertheless, domestic banks and building societies in the UK face stiff competition from subsidiaries of foreign banks and financial institutions as a result of changes in the regulatory environments since the 1980s (Keasey and Watson, 1993). A study by Kosmidou et al (2004a) links the profits of domestic and foreign banks in the UK to their asset and liability composition. They found that both domestic and foreign banks appear to generate profits from both loans and other earning asset portfolios.

\subsection{Econometric Modelling:}

We employ panel data for our econometric analysis: our sample includes 83 banks and the time period spans from 2005 to 2009 . The selection of the sample, which is discussed futher in Section 3.4, is driven by data availability. In a nutshell, and following the literature on bank profitability, we attempt to estimate profitability as a function of business lending while controlling for risk and other variables which might have an impact on profitability, as in Equation (1):

$$
\text { Profitability }_{i, t}=F\left(\text { Business_Lending }_{i, t}, \text { Risk }_{i, t}, \text { Other_Controls }_{i, t}\right)
$$

Subscripts $i$ and $t$ denote banks (the cross-sectional units) and time respectively. The relationship between profitability and the right-hand-side variables are expected to be linear. Equation (1) is as proposed by Abreu and Mendes (2002) and Kolari (2003).

The estimation of (1) would give us an indication of the importance of business lending for bank profitability taking into account other determinants. Our research, however, intends also to establish whether business lending has a systematically different impact on profitability according to bank size and ownership. For this purpose we have created additional regressors by multiplying zero-one dummies for bank size (large or small) and bank ownership (domestic or foreign) with the business lending variable. If significant, the coefficient of these additional regressors indicates the extent to which the average impact of business lending on profitability changes as a result of the bank status, i.e., whether they are large and/or foreign. 
The financial crisis can be expected to have had an impact on the profitability of business lending and, therefore, we control for its occurrence. Similarly to the case of bank size and ownership, we create an additional regressor by multiplying a time dummy equal to one in 2008 and 2009 - which are taken as the crisis years - with the business lending variable. The estimated coefficient represents the impact of the financial crisis on the effect that business lending has on average bank profitability.

We estimate the relationships in Equation (1) by means of fixed effects regressions. This is an appropriate approach to control for bank heterogeneity, their differences in quality, sophistication, business practices and other factors which we cannot observe or measure. The fixed effects soak up all the omitted factors which are particular to each bank and therefore they allow the researcher to explore the relationships between profitability and the explanatory variables within each bank. In the basic fixed effects model, the effect of each explanatory variable is assumed to be identical across all banks. The additional regressors that we have generated through multiplicative dummies (also called 'slope' dummies) serve to test the hypotheses that the effect of our variable of interest - business lending - differs across groups of banks.

As already suggested by this description, fixed effects estimation is based on the assumption that the individual characteristics of each bank - which, if not controlled for, would be part of the error term - are correlated with the regressors and, therefore, without controls for them, the estimated coefficients of the explanatory variables would be biased.

An alternative approach which is widely used in panel data econometrics is random effects estimation. Unlike the fixed effects model, the random effects model assumes that the variation across cross-sectional units is random and, hence, uncorrelated with the regressors. As standard practice, we based the choice between fixed effects and random effects estimation on the results of the Hausman test, which tests whether the errors of the cross-sectional units are correlated with the regressors (Baltagi, 2013). The null hypothesis is that they are not and, therefore, random effects estimation is the preferred model. In our case, the Hausman test always rejected the null hypothesis and, hence, fixed effects estimation was taken as the preferred model.

\subsection{Variable Selection}

Profitability: In this study we use the return on average equity (ROAE) as the measure of profitability. It is a standard measure, which is particularly appropriate under the so-called shareholder value model, since ROAE is the return that bank owners earn on their investment. 
The rate of return on equity should be assessed critically since, by definition, it can be raised by increasing leverage and, hence, risk. ${ }^{2}$

Business Lending: This is the ratio of Corporate and Commercial Lending to Total Assets and is our key variable of interest. As explained in Section 3.2, for our econometric investigation we have created additional regressors by multiplying the business lending variable with zero-one dummies for bank size, ownership and financial crisis. A value of one denotes large banks, foreign banks and crisis years respectively.

Bank Performance Indicators: There is a plethora of indicators that could be used for the evaluation of bank risk or performance. For example, Golin (2001) provides a comprehensive list of over 80 ratios covering the major categories of performance indicators: funding, liquidity, capital, asset quality, profitability and efficiency. Given the cross-sectional nature and the time dimension of our study, data availability restricted the number of indicators suitable to be used as controls in our econometric estimation to eleven.

Three indicators can be used as different proxies for credit risk and the quality of the loan portfolio. (1) The growth rate of gross loans. Rapid growth may be a sign of euphoria and reflect a tendency to under-price risk. (2) The ratio of impaired loans to total loans. Higher values of this ratio are a sign of lower quality of the loan portfolio. (3) The ratio of loan loss reserves to total loans. This ratio can also be related to the quality of the loan portfolio, although the size of reserves is in part likely to reflect a subjective assessment of borrowers' financial conditions. In practice, both the ratio of impaired loans and the ratio of loan loss reserves are likely to track the economic cycle somewhat.

Five indicators are used as proxies for liquidity risk. (1) The loan to deposit ratio. A high value of this ratio may be a sign that the bank may not have enough liquidity to cover unforeseen fund requirements; conversely, a low value may indicate that the bank may not be earning as much as it could. (2) The ratio of core deposits to total assets. As core deposits are not sourced from institutional depositors but from a bank's traditional customers, they are less sensitive than purchased funds to a change in interest rate or a minor deterioration in bank performance; therefore, a high value of this ratio indicates lower liquidity risk. (3) The ratio of securities to total assets. Marketable securities are highly liquid assets and, hence, this ratio is a measure of a bank's liquidity and its ability to pay its short-term obligations. (4) The interbank ratio (interbank assets to interbank liabilities). Interbank assets are loans to other banks or deposits placed with other banks. Interbank liabilities are borrowings or deposits from other banks. Therefore, their

\footnotetext{
${ }^{2}$ The rate of return on equity depends on the rate of return on assets (ROA = Net Income/Total Assets) and on the total value of assets that earn income, which can be raised by using liabilities to pay for assets, i.e., leverage. Hence, ROA x Leverage Ratio (which is defined as Total Assets/Bank Capital) gives the rate of return on equity.
} 
ratio, being a measure of how dependent a bank is on purchased funds - which are more volatile than customer deposits - gives an indication of the bank's liquidity risk. While a value of this ratio greater than one is preferable from a liquidity perspective, this may not be true from a profitability angle. (5) The ratio of loans to total assets. This can be taken as a cruder measure of liquidity, as it compares relatively illiquid loan assets to total assets. A lower value of the ratio indicates a more liquid position. However, this ratio will also tend to vary with market and economic conditions.

We used the equity to asset ratio as a measure of capital strength and solvency, since it represents the proportion of total assets that are financed by stockholders instead of creditors. Higher capital will generally reduce profitability, though it might have a positive effect if it results in a reduction in a bank's risk and, hence, lower cost of funding (Berger, 1995). The relationship between capital and profitability is also likely to be highly cyclical, turning more positive in periods of distress as banks with high capital ratios provide reassurance to investors and are then able to improve their profitability.

Two indicators are used as proxies for a bank's cost efficiency. (1) The ratio of noninterest expenses to total assets. Non-interest expenses are operating expenses or overheads (including employee expenses) plus loan loss provisions. (2) The cost to income ratio. It measures operating cost or overheads as a proportion of total operating income before provisions. This ratio is normally taken as an indicator of efficiency, although its improvement may be unrelated to efficiency as when, for example, lending margins are very high. It can also be distorted by high net income from associates or volatile trading income. Essentially, these two indicators of cost efficiency express the extent of operating expenses in terms of assets and revenue respectively and, thus, low values of these ratios are a sign that a bank is making efficient use of inputs (high cost efficiency).

External/Macroeconomic Controls: We consider two macroeconomic variables. The first is the Bank of England's official discount rates to commercial banks, which we use to control for the influence of monetary policy. Following for example Kashyap and Stein (1995) and Huang (2003), the official discount rate can serve as a proxy for capital scarcity and as a measure of the cost of capital in the economy. The second macroeconomic variable we include is the growth rate of GDP.

\subsection{Sample Selection and Data Sources}

The data used in this study were obtained from Bureau Van Dijk's BankScope Database. We included in the sample only those banks and building societies which met a number of criteria. First, they had to be registered in the UK by the Financial Services Authority and 
resident or operating in UK, regardless of their ownership structure. Second, they had to have complete annual data for the study period.

The institutions included in the sample were then segmented into two asset size categories following Kosmidou et al (2006b). Banks with total assets less than $£ 100$ Billion were classified as small banks, while those with total assets above $£ 100$ Billion were classified as large banks. Using this threshold, the sample contains 12 large banks and 71 small banks. Their average total assets amount to $£ 697,639$ million and $£ 5,647$ million for large and small banks respectively as at 2009 .

We also classified the financial institutions included in the sample according to their ownership structure. Banks for which at least 51 percent of the ownership stake was British as at 2009 were classified as domestic banks; otherwise they were classified as foreign. Using this criterion, 59 banks were classified as locally owned and 24 banks as foreign owned.

Data on macroeconomic indicators were obtained from other sources. Data on the bank rate were obtained from the Bank of England's website, while data on real GDP growth rate were obtained from World Bank's World Development Indicators.

\subsection{Description and preliminary analysis of data}

Table 1 reports means and standard deviations of all our bank-level variables. Given the nature of our enquiry, we also report means and standard deviations separately for the different bank groups (that is, small, large, domestic and foreign banks) for the two key variables considered in our analysis, namely, profitability and business lending. We have broken down the ratio of business lending to total assets into the ratio of business lending to total loans and the ratio of loans to total assets.

\section{INSERT TABLE 1 APPROXIMATELY HERE}

The mean of ROAE is larger for large banks than small ones and that of domestic banks marginally higher than that of foreign banks. The ratio of business loans to total loans is higher for foreign banks than domestic banks and for small banks than large ones, though in the latter case the difference is small. The loan to asset ratio is higher for domestic banks than foreign banks and for small banks than large banks. As a result, business loans are a larger proportion of total assets for small banks than for large banks. Such proportions are similar for foreign and domestic banks.

Before a full econometric analysis of the relationship between profitability and business lending, we performed some preliminary tests on the statistical properties of the data. We first checked for stationarity of our variables by means of three panel unit root tests and, following 
standard procedures, we rejected non-stationarity when variables passed at least two of the tests. ${ }^{3}$ Our variables turned out to be stationary.

Secondly, given the large number of bank-specific variables employed in our analysis, we checked for the possible existence of multicollinearity, since strong correlation among the independent variables would cause unreliable and unstable coefficient estimates. We first looked at the correlation matrix of the bank-specific variables. Table 2 shows that the explanatory variables have low correlations with each other. There is moderate correlation between core deposits and loans (both as a ratio of total assets) but this is well below the critical value of 0.8 which is normally taken as an indication of multicollinearity (Gujarati and Porter, 2009).

\section{INSERT TABLE 2 APPROXIMATELY HERE}

Pairwise correlations are insufficient on their own to detect multicollinearity, since they may be small and yet there could be linear dependence among three or more variables. We looked at the Variance Inflation Factor (VIF) to test for this. As shown il the last row of Table 2, VIFs are low for all variables. Like for pairwise correlations, it is possible to find in the literature various recommendations for acceptable levels of VIF. Nonetheless, even a low recommended maximum VIF value of 4 is much higher than the VIFs of our explanatory variables. ${ }^{4}$ We conclude that multicollinearity is unlikely to be a problem in our econometric estimation.

\section{Empirical Results}

This section analyses the empirical evidence concerning the profitability of business lending in the UK paying particular attention to detecting the existence of size and ownership effects. The analysis is based on the econometric estimation of Equation (1). Our estimation procedure is in a way similar to the general to specific approach in that we start from an unrestricted model which includes all variables and we then restrict it while ensuring that misspecification is not detected and the imposed restrictions are not rejected.

\subsection{Main Regression Results}

Column (1) in Table 3 shows the regression results with all of the eleven bank-level control variables defined earlier. The regression does not include the variable of interest (business lending), the multiplicative dummies and macroeconomic controls. In Column (2), we rerun the regression after removing four variables that were insignificant at the 10 percent level,

\footnotetext{
${ }^{3}$ We conducted three panel unit root tests: Levin Lin and Chu; Im, Pesaran and Shin and PP-Fisher Chi- Square (see Baltagi, 2013)

${ }^{4}$ Moreover, high VIFs may not necessarily be a problem if the variables concerned are used simply as controls while the variable of interest has a low VIF. In any case, rules of thumb for VIFs should always be treated with caution (O’Brien, 2007)
} 
namely, the loan to asset ratio, the loan to deposit ratio, the core deposits to asset ratio and the interbank ratio. The results are in line with our expectations. A growing loan portfolio is associated with a greater return on equity while larger loan loss reserves, greater amounts of impaired loans, higher costs and non-interest expenditure have a negative impact on the return on equity. An increase in equity reduces the return on equity, though it could insulate the bank from financial shocks. Our results show that, in the case of our sample, a greater proportion of securities in total assets has been associated with a lower return on equity, though it could contribute in principle to a reduction in bank liquidity risk (Kolari, 2003).

\section{INSERT TABLE 3 APPROXIMATELY HERE}

In Column (3), we add the variable of interest, business lending, both on its own and interacted with the dummy for bank size. The results show that all the risk control variables maintained their significance and signs, with the exception of the loan loss reserves ratio, which narrowly became insignificant. Business lending has a positive and significant relationship with $R O A E$, implying that business lending is an important determinant of profitability for all UK banks. This result is in line with those of Abreu and Mendes (2002) and Bennaceur and Goaied, 2008) who found that the loan ratio impacted positively on aggregate profits of banks.

However, this is an average result for all banks. In fact, the results in Column (3) reveal the presence of significant size effects. To see it, rewrite the regression equation focusing only on the variables of interest and their estimated coefficients:

$$
\widehat{R O A} E_{i t}=1.08 * \text { Business lending } i t-1.05 * \text { Business lending } \text { lit } * \text { Size }+\cdots+\varepsilon_{i t}
$$

The negative estimated coefficient of the interaction term indicates that, for large banks, the contribution of business loans to profitability (as measured by the return on equity) is less than for small banks and very small. This finding could have different explanations, not necessarily competing. The financial crisis may have hit large banks more severely than small banks and, hence, the need to restructure impaired balance sheets may have resulted in a dramatic contraction of their lending. Moreover, large banks rely on highly volatile wholesale funding sources while small banks traditionally utilise relatively stable core deposits to fund their lending. In fact, DeYoung et al (2004) in their study on the characteristics of community banks versus large banks in the US, found that core deposits as a percentage of assets increases as bank size decreases, suggesting that large banks' funding liquidity risk may have been accumulating over the years. We will attempt to investigate the possible effect of the financial crisis on banks' lending below. Another explanation is more structural: with financialisation, commercial banks - especially large ones - have increasingly acquired investment banking functions and generated profits by mediating transactions in open financial markets. They have also aggressively entered the consumer/household market by boosting their provision of 
mortgages and unsecured loans. Quantitatively, commercial lending may have lost much of its importance for these banks as a major source of bank profits.

In Column (4a), we consider the effect of ownership on profitability. As can be seen, the inclusion of the interaction term of business lending with the ownership dummy weakens the significance of some of the control variables. More importantly, neither business lending on its own nor its interaction with the ownership dummy turn out to be significant. In Column (4b) we include two interaction terms for business lending: one with the size dummy, the other with the ownership dummy. The results have improved: of the control variables, it is only the coefficient of loan loss reserves that remains insignificant. The coefficients of business lending on its own and of business lending interacted with the size dummy are significant, while the coefficient of the interaction term with the ownership dummy is again not significant, as in Column (4a). These findings suggest that bank ownership is not the cause of systematic differences among banks in the extent to which business lending contributes to profitability. This conclusion is similar to that by Kosmidou et al (2004a, 2004b) who found that foreign and domestic banks in UK have a similar composition of assets and liabilities and similar profitability from loans and other earning assets. This is perhaps a result of the intense competition that UK banks face from foreign banks (Keasey and Watson, 1993; Davies, 2002).

In Column (5), we introduce macroeconomic control variables, namely, the official discount rate and economic growth. Most of the explanatory variables retain their signs and significance (with the exception of the securities ratio and the equity ratio). The Bank of England's official discount rates to commercial banks is found to be negatively related to profits (ROAE), potentially supporting Flannery's (1981) hypothesis that an increase in interest rates could likely reduce a bank's earnings via a temporary liquidity crunch and limits on lending. We find the coefficient of the GDP growth rate to be positive, confirming the conventional notion that economic growth is positively associated with bank prosperity.

Since our sample period includes the global financial crisis, we investigate how its occurrence affected the relationships with bank profitability discussed in our paper. In Column (6a) we introduce the interaction term of business lending with the financial crisis dummy. We find that all variables maintain their signs and significance, except for the securities ratio, which becomes marginally insignificant. The coefficient of our new interaction term is negative and significant at the 1 percent significance level, showing that the financial crisis impacted negatively on the profitability of business lending by UK banks. In Column (6b) we investigate whether it is possible to detect size and ownership effects on the profitability of business lending once the impact of the financial crisis is accounted for. The results confirm that while business lending is a significant determinant of the rate of return on equity for all banks, its impact is very small for large banks. We cannot detect any ownership effects. 
Given that the financial crisis has had a clear impact on the profitability of business lending, it is possible that our previous results might have been distorted by the fact that we did not account for the effect of the financial crisis on the control variables. Thus, in Column (7), we interacted the financial crisis dummy with each of the risk controls. We found a statistically significant impact of the financial crisis on the equities ratio and the non-interest expenses ratio. While the equities ratio retains overall an obvious negative effect on profitability, it is the bettercapitalised banks that could record a greater rate of return on equities in the crisis and postcrisis periods. On the other hand, banks with lower operational efficiency - as measured by the non-interest expenses ratio - attained lower profitability. As in Column (6), the financial crisis has been found to have reduced the contribution of business lending to bank profitability. Once again, we detected a strong size effect on the profitability of business lending, which is small for large banks.

\subsection{Conclusions}

This paper addresses the question whether business lending is still an important source of bank profits in the UK banking system. This research question is motivated by the effects of the process of financialisation. It has been argued that one of the consequences of financialisation is a dramatic change in business strategies by financial institutions, which have turned to new fields of profitability - namely, transactions in open financial markets and household/consumer lending - moving away from traditional business lending.

However, the extent to which commercial banks have embraced financialisation and the contribution of business lending to bank profitability are likely to be the result of bank-specific characteristics. This paper investigates, therefore, whether the profitability of business lending is driven by bank heterogeneity or whether it is possible to identify systematic characteristics which affect it. Our results, which consider 83 banks in the UK between 2005 and 2009, find very strong size effects: in particular, while business lending is a statistically significant source of bank profits, its quantitative importance varies dramatically across bank size. For large banks, business lending contributes to the rate of return on equity very little. This finding is not due to the occurrence of the financial crisis. Indeed, large size effects are found even when the financial crisis is controlled for. While we detected strong size effects, we could not detect any ownership effects. The profitability of business lending depends on whether banks are large or small, not on whether they are domestic or foreign. Our finding about the impact of financialisation on business lending, particularly for large banks, echoes those by Narsisyan and Wray (2010) and Lapavitsas and Powell (2013). One possible policy implication is that capital injections into the larger banks per se are unlikely to lead to an expansion of credit to business. 


\section{References:}

[1] Abreu, M. and V. Mendes (2002), 'Commercial Bank Interest Margins and Profitability: Evidence from E.U. Countries', Working Paper Series, Porto.

[2] Aiyar, S. (2011) "How did the crisis in international funding markets affect bank lending? Balance sheet evidence from the United Kingdom", Bank of England Working Paper No. 424, April

[3] Baltagi, B. (2013), Econometric Analysis of Panel Data, Third Edition, Wiley

[4] Bank of England (2014), 'Trends in Lending', October Edition

http://www.bankofengland.co.uk/publications/Documents/other/monetary/trendsoctober14.pdf (Accessed 11/05/2015)

[5] Bennaceur, S. and Goaied, M. (2008), 'The Determinants of Commercial Bank Interest Margins and Profitability: Evidence from Tunisia', Frontiers in Finance and Economics 5 (1): 106-130.

[6] Berger, A. (1995), The relationship between capital and earnings in banking. Journal of Money, Credit and Banking 27(2): 432-456.

[7] Berger, A.N. and Black, L.K., (2011) "Bank size, lending technologies, and small business finance," Journal of Banking \& Finance 35 (3): 724-735.

[8] Bolt, W., Haan, L.D., Hoeberichts, M., Van Oordt, M.R.C., Swank, J. (2012) "Bank profitability during recessions", Journal of Banking and Finance 36: 2552-2564

[9] Bush, O., Knott, S. and C. Peacock (2014) "Why is the UK Banking System so big and is that a problem? Bank of England Quarterly Bulletin Q4: 385-395

[10] Carter, D.A., J.E. McNulty, and J.A. Verbrugge (2004) "Do Small Banks have an Advantage in lending? An Examination of Risk-adjusted Yields on Business Loans at Large and Small Banks", Journal of Financial Services Research 25: 233-252.

[11] Competition Commission (2002) 'Report on the Supply of Banking of Banking Services by Clearing Banks to Small and Medium-Sized Enterprises. London: HMSO (Volumes 1, 2, 3 \& 4).

[12] Davies, H. (2002), 'The single financial market - miracle or mirage?'; British Chamber of Commerce. Available at: http://www.fsa.gov.uk/Pages/Library/Communication/Speeches/2002/sp94.shtml (Accessed 20/08/2011).

[13] DeYoung, R., W. C. Hunter, and G. F. Udell. (2004). "The Past, Present, and Probable Future for Community Banks" Journal of Financial Services Research 25 (2-3): 85-133.

[14] DeYoung, R. and D.E. Nolle (1996), "Foreign-Owned Banks in the U.S: Earning Market Share or buying it?" Journal of Money, Credit and Banking 28:622-636. 
[15] Dolphin, T. (2012) 'Don't bank on it: The financialisation of the UK economy', Institute for Public Policy Research (London)

[16] Epstein, G., ed., (2005) Financialization and the world economy (Cheltenham: Elgar)

[17] Flannery, M.J. (1981),'Market Interest Rates and Commercial Bank Profitability: An Empirical Investigation,' Journal of Finance 26 (Dec), 1085-1102.

[18] Gart, A and Pierce E (1998) Why do large US banks outperform their European counterparts? Studies in Economics and Finance 19(1/2): 27-47

[19] Golin, J., (2001) The Bank Credit Analysis Handbook: A Guide for Analysts, Bankers and Investors. John Wiley \& Sons (Asia) Pre Ltd.

[20] Gujarati, D.N. and D.C. Porter (2009) Basic Econometrics, fifth edition, McGraw Hill

[21] Haynes, G.W., C. Ou, and R. Berney (1999) Small business borrowing from large and small banks, in Business Access to Capital and Credit, edited by Jackson L. Blanton, Alicia Williams, and Sherrie L.W. Rhine, A Federal Reserve System Research Conference, 287-327.

[22] Hein, S.E., T.W. Koch, and S.S. MacDonald (2005), "On the Uniqueness of Community Banks," Federal Reserve Bank of Atlanta Economic Review, First Quarter: 15-36.

[23] HM Treasury (2010), Financing a Private Sector Recovery, Department for Business Innovation \& Skills (BIS).

[24] Huang, Z. (2003), 'Evidence of a bank lending channel in the UK', Journal of Banking and Finance 27: 491-510

[25] Kashyap, A. and Stein, J. (1995), 'The impact of monetary policy on bank balance sheets', CarnegieRochester Conference Series on Public Policy 42:151-195.

[26] Keasey, K. and Watson, R. (1993), 'The Bank Financing of Small Firms in UK: Issues and Evidence, Small Business Economics 6(5): 349-362

[27] Kolari, J.W. (2003) 'Assessing the Profitability and Riskiness of Small Business Lenders in the Banking Industry', SBA Office of Advocacy, Small Business Research Summary No. 229.

[28] Kolari, J. Berney, R. and Ou, C. (1997) 'Small Business Lending and Bank Profitability', Journal of Entrepreneurial and Small Business Finance 5: 1-16

[29] Kosmidou, K., Pasiouras, F. and Floropoulos, J. (2004a), 'Linking profits to asset-liability management of domestic and foreign banks in the UK', Applied Financial Economics 14:1319-1324.

[30] Kosmidou, K., Pasiouras, F., Zopounidis, C. and Doumpos, M. (2004b), 'Foreign versus domestic banks' performance in the UK: a multicriteria approach, Computational Management Science 1: 329-343. 
[31] Kosmidou, K., Pasiouras, F., Zopounidis, C. and Doumpos, M. (2006a), 'A multivariate analysis of the financial characteristics of foreign and domestic banks in the UK', Omega 34:189-195.

[32] Kosmidou, K., Pasiouras, F., Zopounidis, C. and Doumpos, M. (2006b), 'Assessing Performance Factors in the UK Banking Sector: A Multi-criteria Methodology', Central European Journal of Operations Research 14:25-44

[33] Lapavitsas, C., (2011) Theorizing financialization, Work, Employment and Society 25(4): 611-626

[34] Lapavitsas, C. and Powell, J., (2013) Financialisation varied: A comparative analysis of advanced economies, Cambridge Journal of Regions, Economy and Society 6(3): 359-379

[35] Llewellyn, D. (2005), 'Competition and Profitability in European Banking: Why Are British Banks So Profitable? Economic Notes 3: Review of Banking, Finance and Monetary Economics 34: 279-311.

[36] Matthews, K., Murinde, V. and Zhao, T. (2007), 'Competitive conditions among the major British banks', Journal of Banking and Finance 31:2025-2042.

[37] Nakamura, L. I. (1994) "Small Borrowers and the Survival of the Small Bank: Is Mouse Bank Mighty or Mickey? Federal Reserve Bank of Philadelphia Business Review, (November/December): 3-15.

[38] Nersisyan, Y. and Wray, R., (2010), Transformation of the financial system: Financialization, concentration and the shift to shadow banking, in: D. Tavasci and J. Toporowski, eds., Minsky, crisis and development (Basingstoke: Palgrave Macmillan), 32-49

[39] O'Brien, R.., (2007), A caution regarding rules of thumb for Variance Inflation Factors, Quality \& Quantity 41(5): 673-690

[40] Peek, J. and S. Rosengren (1995) "Small business credit availability: how important is size of lender?" Working Papers 95-5, Federal Reserve Bank of Boston.

[41] Peek, J. Rosengren, S. and Kasirye, F. (1999), The poor performance of foreign bank subsidiaries: were the problems acquired or created? Journal of Banking and Finance 23:579-604.

[42] Petersen, M.A. and R.G. Rajan (1994), The benefits of firm-creditor relationships: Evidence from small business data, Journal of Finance 49: 3-37.

[43] Riley, R. Rosazza-Bondibene, C. and G. Young (2014) "The Financial Crisis, Bank Lending and UK Productivity: Sectoral and Firm-Level Evidence", National Institute Economic Review No 228: R17-R34, May

[44] Turati, G. (2002), 'Cost Efficiency and Profitability in European Commercial Banking', PhD Dissertation, Universita, Cattolica del S. Cuore.

[45] White, W. (1998) 'The coming transformation of continental European banking?', Bank for International Settlements Working Paper 54 
Table 1: Descriptive statistics of bank-level variables

\begin{tabular}{|c|c|c|c|c|}
\hline Ratio & Bank group & $\mathbf{N}$ & Mean & Std. Dev \\
\hline \multirow[t]{5}{*}{ Return on Average Equity } & All & 415 & 5.20 & 13.20 \\
\hline & Small & 355 & 4.73 & 11.66 \\
\hline & Large & 60 & 7.97 & 19.95 \\
\hline & Domestic & 295 & 5.02 & 13.80 \\
\hline & Foreign & 120 & 5.67 & 11.55 \\
\hline \multirow[t]{5}{*}{ Business Loans/Total Loans } & All & 415 & 15.99 & 17.90 \\
\hline & Small & 355 & 16.09 & 18.89 \\
\hline & Large & 60 & 15.42 & 10.34 \\
\hline & Domestic & 295 & 14.30 & 15.71 \\
\hline & Foreign & 120 & 20.40 & 22.11 \\
\hline \multirow[t]{5}{*}{ Loans/Total Assets } & All & 415 & 56.42 & 24.16 \\
\hline & Small & 355 & 58.53 & 24.14 \\
\hline & Large & 60 & 43.94 & 20.32 \\
\hline & Domestic & 295 & 60.04 & 22.60 \\
\hline & Foreign & 120 & 46.98 & 25.59 \\
\hline Loan Growth & All & 415 & 14.19 & 37.41 \\
\hline Impaired Loans $^{1}$ & All & 415 & 0.51 & 0.95 \\
\hline Loan Loss Reserves $^{1}$ & All & 415 & 1.14 & 2.71 \\
\hline Loan-to-Deposit Ratio & All & 415 & 119.29 & 108.36 \\
\hline Core Deposits ${ }^{2}$ & All & 415 & 48.39 & 33.50 \\
\hline Securities $^{2}$ & All & 415 & 19.27 & 16.61 \\
\hline Interbank Ratio & All & 415 & 160.38 & 176.52 \\
\hline Equity $^{2}$ & All & 415 & 8.62 & 9.60 \\
\hline Non-Interest Expenses ${ }^{2}$ & All & 415 & 2.63 & 5.38 \\
\hline Cost-to-Income Ratio & All & 415 & 68.75 & 25.69 \\
\hline
\end{tabular}


Table 2: Correlation matrix and Variance Inflation Factors (VIF) of the bank-specific variables

\begin{tabular}{|c|c|c|c|c|c|c|c|c|c|c|c|c|c|}
\hline $\begin{array}{l}\text { Return on } \\
\text { equity }\end{array}$ & $\begin{array}{l}\text { Return } \\
\text { on } \\
\text { equity } \\
1.00\end{array}$ & $\begin{array}{l}\text { Business } \\
\text { loans }^{1}\end{array}$ & $\begin{array}{l}\text { Loan } \\
\text { growth }\end{array}$ & $\begin{array}{l}\text { Impaired } \\
\text { Loans }^{2}\end{array}$ & $\begin{array}{l}\text { Loan } \\
\text { loss } \\
\text { reserves }^{2}\end{array}$ & $\begin{array}{l}\text { Loan-to } \\
\text { deposit } \\
\text { ratio }\end{array}$ & $\begin{array}{l}\text { Core } \\
\text { deposits }^{1}\end{array}$ & Securities ${ }^{1}$ & $\begin{array}{l}\text { Interbank } \\
\text { Ratio }\end{array}$ & Loans $^{1}$ & Equity $^{1}$ & $\begin{array}{l}\text { Non- } \\
\text { interest } \\
\text { expenses }\end{array}$ & $\begin{array}{l}\text { Cost- } \\
\text { to- } \\
\text { income }\end{array}$ \\
\hline $\begin{array}{l}\text { Business } \\
\text { loans }^{1}\end{array}$ & 0.16 & 1.00 & & & & & & & & & & & \\
\hline $\begin{array}{l}\text { Loan } \\
\text { growth }\end{array}$ & 0.25 & 0.28 & 1.00 & & & & & & & & & & \\
\hline $\begin{array}{l}\text { Impaired } \\
\text { loans }^{2}\end{array}$ & -0.21 & 0.26 & -0.02 & 1.00 & & & & & & & & & \\
\hline $\begin{array}{l}\text { Loan loss } \\
\text { reserves }^{2}\end{array}$ & -0.09 & 0.27 & -0.05 & 0.27 & 1.00 & & & & & & & & \\
\hline $\begin{array}{l}\text { Loan-to- } \\
\text { deposit } \\
\text { ratio }\end{array}$ & -0.10 & 0.19 & 0.07 & 0.07 & 0.01 & 1.00 & & & & & & & \\
\hline $\begin{array}{l}\text { Core } \\
\text { deposits }^{1}\end{array}$ & 0.06 & -0.46 & -0.11 & -0.22 & -0.28 & -0.32 & 1.00 & & & & & & \\
\hline Securities $^{1}$ & 0.00 & 0.02 & -0.03 & 0.15 & 0.09 & -0.02 & -0.38 & 1.00 & & & & & \\
\hline $\begin{array}{l}\text { Interbank } \\
\text { ratio }\end{array}$ & 0.04 & -0.10 & 0.13 & -0.07 & -0.01 & -0.16 & 0.24 & -0.33 & 1.00 & & & & \\
\hline Loans $^{1}$ & 0.03 & -0.13 & 0.03 & -0.10 & -0.21 & -0.01 & 0.63 & -0.50 & 0.18 & 1.00 & & & \\
\hline Equity $^{1}$ & 0.01 & 0.14 & 0.13 & -0.08 & 0.05 & 0.15 & -0.25 & 0.03 & -0.07 & -0.15 & 1.00 & & \\
\hline $\begin{array}{l}\text { Non- } \\
\text { interest } \\
\text { expenses }\end{array}$ & -0.06 & 0.15 & 0.12 & 0.04 & 0.16 & -0.01 & -0.23 & 0.03 & -0.08 & -0.27 & 0.22 & 1.00 & \\
\hline $\begin{array}{l}\text { Cost-to- } \\
\text { income }\end{array}$ & -0.52 & -0.16 & -0.14 & -0.05 & 0.06 & -0.04 & -0.01 & 0.03 & -0.05 & -0.08 & -0.06 & 0.27 & 1.00 \\
\hline VIF & -- & 1.2207 & 1.0323 & 1.6292 & 1.9755 & 1.0074 & 1.0594 & 1.0598 & 1.0022 & 1.0716 & 1.1930 & 1.0279 & 1.3748 \\
\hline
\end{tabular}


Table 3: Regression results

Dependent variable: ROAE

Method: Panel Least Squares

Effects Specification: Cross Section Fixed Dummy Variables

Sample: $2005-2009$

Periods included: 5

Cross-sections included: 83

Total panel (balanced) observations: 415

(1)

Business loans ${ }^{1}$

Business loans ${ }^{1} *$ size

Business loans ${ }^{1}$ * ownership

Business loans ${ }^{1}$ * crisis

Impaired loans ${ }^{2}$

Loan loss reserves ${ }^{2}$

Loan-to-deposit ratio

Core deposits $^{1}$

Securities ${ }^{1}$

Interbank ratio

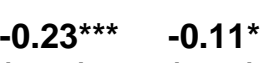

(0.00) (0.06)

$-3.12 * \star \star$

$-3.05^{* * *}-3.84^{* * *}$

(0.00)

$0.00)$

(0.00)

$(0.06)$

$(0.06)$

$(0.13)$

0.01

$(0.47)$

$-0.04$

(0.50)

(0.00)

0.00 (4a)

1.08*** -0.04

(0.00) (0.73)

$-1.06^{\star \star *}$

(0.00)

(4b)

0.95 *

(5) (6a)

(6b)

(7)

$-0.98^{\star * *}-0.99^{* * *}$

$(0.00) \quad(0.01)$

1.09***

$-0.98^{* * *}-0.99 * * *$

$-0.93 * * * \quad-0.91 * * \quad-0.95 * * *$

(0.01) (0.01)

(0.01)

(0.01)

(0.01)

$\begin{array}{lll}0.23 & 0.13 & 0.08 \\ (0.13) & (0.38) & (0.61)\end{array}$

(0.13)

(0.38)

$0.61)$

$-0.18^{\star \star *}-0.18^{\star \star *}-0.18^{\star \star *}$

(0.00) (0.00) (0.00)

$-3.89 * \star *$

$-3.81 * * * \quad-2.99 * * *$

$-2.73^{\star * *}-2.73^{\star * *} \quad-2.77^{\star * *}$

(0.00)

(0.00)

$(0.00)$

(0.00)

$-2.73$

-2.77
$(0.00)$

$-0.43$

$-0.41$

$-0.46 *$

-0.50 **

-0.42 *

$-0.13^{* *}$

-0.12 *

(0.04)

$-0.08$

$-0.08$

$-0.09$

$-0.09 *$

(0.47)

Loans $^{1}$

0.04

(0.47) 


\begin{tabular}{|c|c|c|c|c|c|c|c|c|c|}
\hline & (1) & (2) & (3) & $(4 a)$ & $(4 b)$ & (5) & (6a) & (6b) & (7) \\
\hline Equity $^{1}$ & $\begin{array}{l}-0.15^{*} \\
(0.08)\end{array}$ & $\begin{array}{l}-0.12^{*} \\
(0.09)\end{array}$ & $\begin{array}{l}-0.14^{*} \\
(0.07)\end{array}$ & $\begin{array}{l}-0.15^{\star} \\
(0.06)\end{array}$ & $\begin{array}{l}-0.15^{\star} \\
(0.06)\end{array}$ & $\begin{array}{l}-0.11 \\
(0.15)\end{array}$ & $\begin{array}{l}-0.14^{*} \\
(0.06)\end{array}$ & $\begin{array}{l}-0.15^{\star} \\
(0.06)\end{array}$ & $\begin{array}{l}-0.28^{\star \star \star} \\
(0.01)\end{array}$ \\
\hline Non-interest expenses ${ }^{1}$ & $\begin{array}{l}-0.72^{\star *} \\
(0.02)\end{array}$ & $\begin{array}{l}-0.79 * * * \\
(0.01)\end{array}$ & $\begin{array}{l}-0.58 * * \\
(0.05)\end{array}$ & $\begin{array}{l}-0.47 \\
(0.13)\end{array}$ & $\begin{array}{l}-0.53^{*} \\
(0.08)\end{array}$ & $\begin{array}{l}-0.69 * * \\
(0.02)\end{array}$ & $\begin{array}{l}-0.74^{\star *} \\
(0.01)\end{array}$ & $\begin{array}{l}-0.72 * * \\
(0.02)\end{array}$ & $\begin{array}{l}-0.98 * * * \\
(0.00)\end{array}$ \\
\hline Cost-to-income ratio & $\begin{array}{l}-0.27^{* * *} \\
(0.00)\end{array}$ & $\begin{array}{l}-0.27^{\star * *} \\
(0.00)\end{array}$ & $\begin{array}{l}-0.28^{\star \star *} \\
(0.00)\end{array}$ & $\begin{array}{l}-0.28 * * * \\
(0.00)\end{array}$ & $\begin{array}{l}-0.28 * * * \\
(0.00)\end{array}$ & $\begin{array}{l}-0.27^{* * *} \\
(0.00)\end{array}$ & $\begin{array}{l}-0.28^{* * *} \\
(0.00)\end{array}$ & $\begin{array}{l}-0.28^{* * *} \\
(0.00)\end{array}$ & $\begin{array}{l}-0.27^{* * *} \\
(0.00)\end{array}$ \\
\hline Bank rate & & & & & & $\begin{array}{l}-2.67^{* * *} \\
(0.00)\end{array}$ & & & \\
\hline GDP growth & & & & & & $\begin{array}{l}2.03^{* * *} \\
(0.00)\end{array}$ & & & \\
\hline Equity $^{1} *$ crisis & & & & & & & & & $\begin{array}{l}0.25^{\star *} \\
(0.01)\end{array}$ \\
\hline Non-interest expenses ${ }^{1} *$ crisis & & & & & & & & & $\begin{array}{l}-0.75^{\star * *} \\
(0.00)\end{array}$ \\
\hline $\mathrm{R}^{2}$ & 0.63 & 0.63 & 0.62 & 0.61 & 0.62 & 0.64 & 0.64 & 0.64 & 0.65 \\
\hline Adj $R^{2}$ & 0.53 & 0.53 & 0.51 & 0.50 & 0.51 & 0.53 & 0.54 & 0.53 & 0.55 \\
\hline F-statistic & $\begin{array}{l}5.91^{\text {*** }} \\
(0.00)\end{array}$ & $\begin{array}{l}6.19 \text { *** } \\
(0.00)\end{array}$ & $\begin{array}{l}5.78 \text { *** } \\
(0.00)\end{array}$ & $\begin{array}{l}5.59 \text { *** } \\
(0.00)\end{array}$ & $\begin{array}{l}5.72^{\text {*** }} \\
(0.00)\end{array}$ & $\begin{array}{l}6.01^{* * *} \\
(0.00)\end{array}$ & $\begin{array}{l}6.18^{\text {*** }} \\
(0.00)\end{array}$ & $\begin{array}{l}6.09 * * * \\
(0.00)\end{array}$ & $\begin{array}{l}6.42^{\star * *} \\
(0.00)\end{array}$ \\
\hline DW statistic & 1.90 & 1.89 & 2.01 & 1.97 & 2.01 & 2.04 & 1.99 & 1.99 & 1.88 \\
\hline
\end{tabular}

Notes: ${ }^{* \star}, \star \star \star *$ denote significance at 1,5 and 10 percent respectively. Numbers in parentheses are probability values.

${ }^{1}$ As a ratio of total assets

2 As a ratio of total loans 